\title{
North American Ginseng Extract AFX-2
}

National Cancer Institute

\section{Source}

National Cancer Institute. North American Ginseng Extract AFX-2. NCI Thesaurus. Code C99122.

An orally available proprietary aqueous extract from the North American ginseng (Panax quinquefolius) dried root, primarily containing poly-furanosyl-pyranosyl-saccharides, with potential immunostimulating activity. Upon administration, North American ginseng extract AFX-2 may stimulate the proliferation and activation of B-lymphocytes and stimulates Ig G production by B cells. Also, this agent induces maturation of dendritic cells, induces T cell proliferation and activates peritoneal exudate macrophages leading to an increase in the production of the cytokines interleukin - 1 and -6, tumor necrosis factoralpha, interferon-gamma and nitric oxide. 